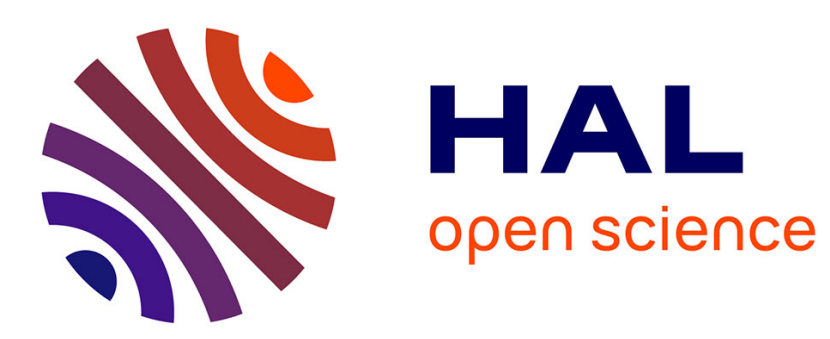

\title{
Making democratic contestation possible: public deliberation and mass media regulation
}

Charles Girard

\section{To cite this version:}

Charles Girard. Making democratic contestation possible: public deliberation and mass media regulation. Policy Studies, 2015, The Sites of Deliberative Democracy, 36 (3), pp.283-297. 10.1080/01442872.2015.1065968 . hal-01758578

\section{HAL Id: hal-01758578 \\ https://hal.science/hal-01758578}

Submitted on 14 Feb 2020

HAL is a multi-disciplinary open access archive for the deposit and dissemination of scientific research documents, whether they are published or not. The documents may come from teaching and research institutions in France or abroad, or from public or private research centers.
L'archive ouverte pluridisciplinaire HAL, est destinée au dépôt et à la diffusion de documents scientifiques de niveau recherche, publiés ou non, émanant des établissements d'enseignement et de recherche français ou étrangers, des laboratoires publics ou privés. 
Policy Studies, 36 (3), 2015, p. 283-297.

[http://dx.doi.org/10.1080/01442872.2015.1065968]

Making democratic contestation possible: public deliberation and mass media regulation

\section{Charles Girard}

Philosophy, Université Jean Moulin Lyon 3

1 rue de l’Université, Lyon, 69007, France

charles.girard@univ-lyon3.fr

Charles Girard is Associate Professor in Philosophy at Université Jean Moulin Lyon 3, where he teaches political, legal and moral philosophy. His work focuses on democratic theory, fundamental rights and freedom of expression. 


\section{Making democratic contestation possible: public deliberation and mass media regulation}

While recent democratic theory has insisted upon the contestability of public policies as a key source of democratic legitimacy, the role mass media should play in fostering public contestation has yet to be specified. The role of deliberative theory in particular should be to try to identify which standards mass communication needs to meet in order to provide a general forum for democratic contestation. This article focuses on the theoretical foundations of such a project. It puts forward three claims. First, the contestability of public policy can only be a source of democratic legitimacy if citizens have the opportunity to participate in public contestation through - among other forums - a general public forum that is endowed with a deliberative dimension. Second, media pluralism alone is insufficient in providing such a public forum: both external standards (related to the independence of mass media) and internal standards (related to the norms guiding media practices) need to be satisfied. Third, and as a consequence of the preceding two, the democratic contestability of public policies presupposes effective mass media regulation that goes beyond the promotion of media pluralism. Democratic contestation requires more than a "marketplace of ideas".

Keywords: contestatory democracy; deliberative democracy; contestation; public sphere; mass media; regulation; marketplace of ideas

Recent democratic theories have insisted upon the contestability of public policies as a key principle of democracy. According to deliberative democrats and neo-republicans, public policies are legitimate not simply because of their substantive content or procedural origin, but because they can be contested, and sometimes revised, even after they have been enacted (Dryzek 2010; Pettit, 2012). This normative claim, which breaks with classical accounts of democratic legitimacy, echoes a worldwide trend in the 
evolution of democratic regimes, namely, the increasing degree to which political discourses and decisions may be contested, not only by parties, unions or lobbyinggroups, but also by citizens, associations, and social movements. In formal and informal arenas, in local meetings or online forums, citizens have growing opportunities to participate in the public evaluation of public policies, and they sometimes manage to compel public authorities to revise them.

While deliberative democrats have especially insisted on the way opportunities for contestation provide “grist for deliberative engagement” (Dryzek 2006, vii), the role the mass media should play in the structuring of a contestatory public sphere has yet to be convincingly specified. Since Habermas’ seminal work on the public sphere (Habermas 1962), political theorists have tried to identify the conditions under which public communication could at the same time favor the grounding of public opinion on citizens' discursive interactions within civil society, and ensure that public opinion efficiently contest public policies when needed (Habermas 1992; Calhoun 1992; Gripsrud and al. 2011). While normative media studies offer various accounts of what role mass communication should play in the public sphere (Dahlgren 2009; Coleman and Blumler 2009), normative political theory has mostly stayed at a distance, focusing on face-to-face or online deliberations rather than on the enabling role of mass media in the context of deliberative democracy (Chambers, 2012). As a consequence, productive encounters between the two fields have been relatively limited (for exceptions, see Chambers and Costain 2000; Maia 2012).

The recent "systemic” turn in deliberative democracy (Dryzek 2010; Parkinson and Mansbridge 2012) has nonetheless underscored the decisive role of mass media as a transmitter that connect multiple local arenas and sub-publics (scattered throughout the democratic system), and provide a platform within which public issues can be discussed 
and publicly criticized at the large scale. Analyses grounded in deliberative theory tend to focus especially on the role mass media can play either as broadcasters of smallgroup deliberations (Parkinson 2006) or of televised debates (Coleman 2013). But mass media also constitute an overarching public stage, on which a small set of discourses may gain maximal public visibility and thus contribute to shaping citizens’ political opinions, and potentially influence political decision-makers. Normative political theory thus needs to define which standards mass media should meet if they are to provide a forum for the deliberative contestation of public policies. This article focuses on the theoretical foundations of such a project. While concerned with the importance of media regulation for deliberative democracy, it does not deal specifically with the difficulties associated with the rise of new media and the challenges the new media landscape creates for democracy (Keane, 2013).

I put forward three main claims. First, the contestability of public policy can only be a source of democratic legitimacy if citizens have the opportunity to participate in public contestation through - among other forums - a general public forum that is endowed with a deliberative dimension. Second, media pluralism alone is insufficient in providing such a public forum: both external standards (those related to the independence and inclusiveness of mass media) and internal standards, (those related to the norms guiding media practices) need to be satisfied. Third, and as a consequence, the democratic contestability of public policies presupposes effective mass media regulation that goes beyond the promotion of media pluralism.

To make this case, I draw not only on recent contributions to deliberative theory, but also on other works linking the idea of democratic contestation to public deliberation. In the first section, I offer a critical take on "contestatory democracy," as developed in Philip Pettit's neo-republican account. While this model explains why 
genuine contestability requires deliberation, as well as inclusion and responsiveness, it excessively narrows the scope of citizens' participation. Contestation can only be made democratic if the task of identifying and sorting out competing contestatory claims is not entirely delegated to experts. There should be, in particular, a general forum in which criticisms of public policies as advanced by citizens, associations, and social movements can be publicly expressed and made accessible to all. In the second section, I consider how mass media could help create such a forum and foster the conditions for democratic contestability. In order to refute the assumption that media pluralism alone suffices to endow the general public forum with a deliberative dimension, I criticize attempts to make the "marketplace of ideas" a model for mass deliberation, focusing in particular on Benjamin Page’s pluralist approach. In the concluding section, I make a deliberative case for mass media regulation, and identify regulatory resources - in journalism ethics, social criticism and media law - with which deliberative theory needs to engage to understand how democratic contestation can be made possible.

\section{Making democracy contestatory, making contestation democratic}

\section{Why contestatory democracy?}

Contestatory democracy makes public contestability the keystone of self-government. What makes contestatory democracy appealing, according to Pettit, are the shortcomings of the majoritarian and pluralist conceptions of democracy with which it breaks. These concern mainly their inability to ensure that public policies track citizens' interests and views, and their inability to offer a convincing model of citizens' control over government. 
Pluralist conceptions (Truman 1951, Dahl 1956, Stigler 1971) suggest that free political competition between interest-groups can, under an appropriate institutional framework, prevent lasting forms of domination. According to this conception, the pursuit by each group of its own self-interest will spontaneously result in equilibrium, with competing interests balanced as best as possible. Interest-group pluralism renounces the idea that democratic government requires a collective intention guided by collective reason, because it assumes an "invisible hand" at work, thus conjuring some “sort of magic” (Pettit 1997, 203).

Pluralists conceptions also offer a weak interpretation of what is required for enabling citizens' control over government: the idea is that "if people are generally represented in such interest-groups, then the influence of those groups over government, proportional as it is likely to be to their numbers, can be expected to be utilitarian in its overall effect” (Pettit 2012, 250). But there is no reason to believe that the influence of the various interest-groups on the government will be based on the size of their constituencies rather than on their financial and organizational resources. Neither the tracking of citizens' interests and ideas by public policies, nor the actual influence of citizens can be secured via the free competition of uncoordinated forces.

By contrast, majoritarian, or “populist,” conceptions of democracy acknowledge the importance of collective action. Drawing on Rousseau (1762), they understand political decision-making as a procedure through which the will of the people is expressed. Such a view is also problematic, however, since nothing guarantees that the "will” supposedly expressed will be rational and serve the genuine interests and ideas of the citizenry, as opposed to the particular interest of a tyrannical majority. When they fail to take into account the minorities’ interests, majoritarian procedures can easily lead to the "ultimate form of arbitrariness" (Pettit 1997, 8). 
Moreover, while populist conceptions hail citizens’ participation as the best way to ensure the people's actual control of the government, they do not offer a plausible view of citizens' motivations. To ask each citizen to adopt the general viewpoint of the people rather than her own particular viewpoint is to set an impossible task. This problem, according to Pettit, plagues any theory that sees citizens as intentionally imposing a common direction on government. "The intention-direction model fails” because it requires citizens (and politicians) to "form judgments about what the public interest requires (...) in full sensitivity to the range of relevant concerns, however altruistic", and to act on the basis of those judgments "without letting private interest of other pressures warp the exercise” in any way (Pettit 2012, 247). One does not need to suppose every man a knave, to find this view to be too demanding.

Contestatory democracy, by contrast, does not foreground spontaneous equilibrium or virtuous will: it foregrounds reason. For citizens to control government, and for their ideas and interests to be tracked by public policies, what is needed is neither pluralism alone, nor consent, but contestability: it must be possible for citizens to publicly criticize policies and to impose their revisions when needed. While the will of the people and the individual consent of each citizen cannot be at the origin of all (or most) policies in large and complex societies, all policies can be open to some form of contestation. What makes democracy different, then, is that it allows citizens to ask for amendments of the rules to which they are submitted. An individual is autonomous, not when she is the author of all her desires and belief, but when she is able to revise any given belief or desire if she has good reasons to do so. Similarly, the people are "selfruling or democratic" when "they are able to contest decisions at will and, if the contestation establishes a mismatch with their relevant interests or opinions, able to force an amendment” (Pettit 1997, 186). But can public policies be made contestable in 
such a way that citizens can both genuinely influence them and truly be protected against political domination?

\section{Conditions for contestability}

Three minimal conditions for contestability can be distinguished: there must be a basis for contestation, a channel for the expression of dissenting voices, and a forum where they can be met with a response. Democracy should be deliberative, inclusive and responsive.

The need for a basis offers an original justification for public deliberation. For contestation to be possible there must be something to be evaluated and criticized. This includes not only the policies that have been decided, but also the reasons supporting them and motivating their selection. If deliberation, in which participants exchange reasoned opinions on the merits of competing policies, is preferable to bargaining, in which participants exchange threats and promises, it is only insofar as deliberation produces reasons, which can still be contested after the decision has been made. In bargaining, only the fairness of the bargaining rules is open to criticism, since no justifications are required. Deliberation, on the contrary, brings out justifications that are open to contestation by anyone, since "you do not have to have any particular weight or power, at least not in principle, in order to be able to mount a reasonable challenge to a reasoned decision” (Pettit 1997, 188).

Citizens also need a channel through which they can make their voice heard. It must be possible for them to make their complaints and criticisms public. Democracy, as a consequence, needs to be fully inclusive. Each social group should be represented wherever decisions are made or wherever they are criticized. A social group can only be said to have a voice for contestation insofar as its members are capable of protesting 
against the legislature, administration or judiciary if "they can make themselves heard in decision-making quarters” (191).

Finally, democratic institutions should be responsive to contestation. Citizens’ claims must not only be heard, but also assessed and, when found to be compatible with the public interest, satisfied. They must provoke an adequate response in a political forum. This means that forums that make it possible for individuals or groups to claim that some policies unduly sacrifice their interests, to appeal against them, and to sometimes win on appeal, should be available.

Now, what kinds of forums are best suited to enable and support contestability? An obvious candidate is the general public sphere, especially in such instances where social movements manage to attract public attention on particular forms of domination that call for policy revisions. But Pettit refuses to consider the rise of "popular movement, widespread controversy and debate, and progressive, legislative adjustment” as a typical image of the contestation process. When considering the implementation of contestability, to think of the public success of the women's movement, the green movement or the gay rights movements "is not inappropriate [...] but it is important to recognize that there should also be other, less heroic procedures available for giving a hearing to contestation” (195). Relying on "heroic" debates in the general public sphere as a systematic mechanism for citizens' contestations is admittedly impossible, but Pettit's concerns do not stop with feasibility: his reluctance to consider the general public sphere as an essential forum for public contestation stems from what he perceives to be the irrationality of mass-media dominated "popular debate”. Suggesting alternatively to create cross-party committees, standing appeals boards or expert commissions, he claims that complaints should in many cases "be depoliticized and should be heard away from the tumult of popular discussion and away, even, from the 
theatre of parliamentary debate” (196). Issues related to crime, for instance, should not be left to public, politicized forums, since mass-media mediated popular debates systematically sanction excesses of leniency and never excesses of harshness in the treatment of criminals. This "unbalanced pattern of triggering controls is exacerbated by the fact that the politicians who are called upon to respond to any outrage are expected to manifest concern in a manner that can communicate itself in the newspaper headline or in the television sound-bite” (197). In this view, contestatory forums can only ensure a rational assessment of citizens' complains if they are isolated from public opinion. But can they then remain democratic?

\section{Is contestatory democracy democratic enough?}

By making the idea of citizens' control plausible in complex societies, contestatory democracy offers a view of self-government that is more feasible than the populist model and less irresponsible than the pluralist one. Furthermore, it echoes the growing tendency in recent democratic theory to take into account the fragmentation and multiplication of the decision-making arenas (Habermas 1992, Dryzek 2010). However, its insistence on protecting the rationality of the contestatory processes by “depoliticizing” them appears to undermine its democratic ambition.

Pettit's sombre diagnosis regarding the irrationality of mass-media mediated debates would be neither out of place, nor excessive, in a work of media criticism. It is less expected in a normative theory of democracy, which attempts to sketch a view of democratic government that might guide the reform of existing regimes. Although Pettit thinks that democracies should provide public funding for quality mass media (Pettit 2012, 234), he does not consider the possibility of reforming mass media into a more rational forum, as well as more welcoming to the expression, discussion and evaluation of citizens' complaints. He is correlatively reluctant to give any substantive role to 
citizens in the evaluation of public complaints. This reluctance echoes his scepticism regarding the judgment citizens can exert when they vote, as he insists that his model “does not presuppose that when people go to the polls, they assume a deliberative profile and express their considered, detached judgment on what is for the best overall” (Pettit 1997, 191-192). Similarly, when participating in processes of public contestation, citizens are not expected, in his view, to a "assume a deliberative profile".

This makes it difficult to consider the "contestatory citizenry” he evokes (Pettit 2012, 225) as self-ruling. For public policies to be appropriately contested, it is necessary that citizens' complaints be rationally assessed in the light of the public interest. In the same way an individual who revises her beliefs regularly, but in an entirely arbitrary way, will not be said to be autonomous, a people who contest its government's decisions regularly, but in an arbitrary way, will not be said to be selfruling. But it is also required that citizens have the possibility in some cases to judge by themselves - in a context favourable to collective and individual deliberation - whether the complaints publicly expressed should indeed compel public authorities to revise previous decisions. The evaluation of these complains in the light of the public interest should not be left exclusively to experts. In the same way an individual who regularly considers changing some of her beliefs or desires, but only does so when a tutor gives her the permission or the order to do so, would hardly be seen as autonomous, a people who asks for revisions of its laws, but systematically relies on experts to sort out and judge these demands, can hardly be seen as self-ruling Pettit believes that "contestatory democracy requires that the demos, and the legislative representatives of the demos, generally tie their hands and gag their mouths” (197), by delegating decisions regarding citizens' contestations to groups of independent and depoliticized experts, but how can it then retain its democratic character? Inclusion appears to have been sacrificed to 
rationality: contestatory democracy so conceived considerably narrows the scope of citizens’ participation.

The alternative would be to endow citizens with the ability not only to form a judgment on their particular interests and to appeal particular policies that concern them, but also to form a rational judgment on the appropriateness of other policies and complaints in light of the public interest. But how can they do so if they do not have access to a general forum where they are able to deliberate on these topics? An essential condition to enable citizens to adopt such a perspective on the public expression of political complaints is the existence of mass media that do not impede, but favour largescale deliberative exchanges.

To consider the deliberative potential of the mass-media dominated public sphere is not to suggest going back to the discredited view according to which the people could gather in a single arena to express its will, nor is it to ignore the many structural sources of irrationality and power asymmetries embedded in media systems. The social complexity and fragmentation of the contemporary political process should not prevent us from investigating the potential of a reformed mass media system to offer a forum for contestatory democracy, which would allow citizens to participate not only in the formulation of political claims but also in the evaluation and criticism of those claims.

\section{Why pluralism is not enough: the inadequacy of the "marketplace of ideas" model}

\section{The deliberative dimension of the public sphere}

A deliberative view of democracy that makes contestability a core principle but 
rejects Pettit's narrow view of citizens' participation cannot avoid asking what standards mass media should comply with in order to sustain a general public sphere that could also be a forum for the contestation of public policies. Yet, normative political theory falls short in providing a satisfactory answer to this question. This is mainly due to the frequent assumption that protecting mediated communication from corrupting influences is enough. While the "marketplace of ideas" model is the most obvious and radical expression of this assumption, and as such deserves special attention, it is worth noting that some version of this assumption can be identified in many theories of deliberative democracy, including the one advocated by Habermas.

Having partially renounced his initial and rather pessimistic account of contemporary mass media's democratic potential (Habermas 1990), Habermas now insists on the importance of mass communication via the mass media. If the public sphere is to operate as "an intermediary system of communication between formally organized and informal face-to-face deliberations in arenas at both the top and the bottom of the political system” (Habermas 2006, 415), mass communication needs to connect the main institutions of the political systems (parliaments, courts, administrative agencies, government) to networks of communication that disseminate the opinions originating from politicians and political parties, lobbyists and pressure groups, as well as citizens, activists and actors of civil society. These opinions, selected and shaped by the mass media, reach broad and partly overlapping audiences. In Habermas' view, the flows of communication produced not only by citizens, journalists and politicians, but also by advocates, lobbyists, experts, moral entrepreneurs and intellectuals, make it possible for deliberation to operate "across the system as a whole" (416). 
Notwithstanding the asymmetrical structure of mass communication, Habermas claims that the general public sphere could generate considered public opinions provided that two conditions are met. Firstly, the independence of the media system, which implies its clear demarcation both from the state and the market, is necessary in order to prevent asymmetries in media power from corrupting mass communication. Secondly, a feedback loop must exist between mass communication and civil society, to allow for citizens' participation in public discourse, as they need "to give voice to society's problems and [to] respond to the issues articulated in elite discourse” (421).

These two "external" standards are hardly sufficient, however. It is admittedly essential that social, economic and political groups not be allowed to turn the mass media into private instruments of propaganda. It is equally essential that whole subpublics not be prevented from publicly reacting to media discourses and from making their reaction heard, as is so often the case. But what are the "internal" standards that the mass media should also satisfy? When asserting that the media system should not only be independent but also self-regulating, Habermas suggest it should operate "in accordance with its own normative code” (419), but he does not specify what the democratic requirements of such a code would be. While it is plausible that under conditions of independence and inclusion, mass communication could shape influential opinions, it is much more difficult to understand how media practices and discourse could spontaneously produce considered opinions. The existence of a free press and independent media, the absence of corrupting influence and the engagement of citizens cannot be expected to ensure the sort of deliberative rationality that a contestatory forum requires. As we saw in the first section, such a forum needs to be both inclusive and deliberative: it needs to favour informed collective reasoning on public policies. While certainly needed, pluralism alone is not enough to create such setting. 


\section{The Marketplace of Ideas}

The claim whereby the implementation of external standards securing pluralism is all the media regulation needed in a democracy has found its clearest expression in the marketplace of ideas model. What was simply a metaphor when Oliver Wendell Holmes wrote, in his minority opinion in Abrams vs. United States, that "the best test of truth is the power of the thought to get itself accepted in the competition of the market”, has since been systematized into a model (Schmuhl and Picard 2005) that remains authoritative in many areas of media law, media research and public policy. The idea that true (or at least enlightened) opinions will prevail in public debate, under conditions of diversity and competition, still exerts a considerable influence on conceptualizations of both public debate and media regulations (see for instance Blocher 2008, Harris, Rowbotham and Stevenson 2009; Klocke and McDevitt, 2013). It has also inspired, within normative political theory, a definition of normative standards for mass deliberation. While deliberative democracy usually rejects the interest-group pluralism view of democracy, it sometimes adopts the marketplace pluralism view of public debate. A paradigmatic case is Benjamin Page's model of mediated deliberation (Page 1996), which still informs many analyses of media debates (Barabas 2004; Church 2010).

In Page's view, public deliberation is needed to ensure that the public's policy preferences, upon which democratic decisions should be based, "are informed, enlightened and authentic” (Page 1996, 1). The main threat to the democratic process is not the irrationality of the public, which is a myth (Page and Shapiro, 1992), but the lack of a proper deliberative context in which the general public can participate in the evaluation and contestation of public policies. In complex societies, public deliberation 
can only be drastically decentralized or mediated. Mediated deliberation presupposes a division of labor in which "a small set of representatives or surrogate deliberators, perhaps (...) professional policy experts and communicators” is in charge of studying policy and addressing the public (Page 1996, 4). It also presupposes the engagement of the citizenry: large audiences of ordinary citizens should be involved in political mass communication. But how can such a division of labor ensure the formation of considered opinions? Page assumes that "if extensive political information is available somewhere in the system, not everyone has to pay attention to it all the time; a lot of information, and reasonable conclusion from it, will trickle out through opinion leaders and cue givers to ordinary citizens, who can deliberate about it in their own small, faceto-face groups of family, friends, and co-workers” (7).

This assumption explicitly draws on the marketplace of ideas model, according to which competition between a sufficiently diverse set of views will guarantee that truth defeat falsehood in public debate. Under this assumption, diversity and free competition are enough to guarantee that public communication produce enlightened judgments. Page indeed considers that "the average citizen has a good chance of arriving at sound opinions, so long as good information is available somewhere, and so long as there is vigorous competition among different ideas and interpretations, even if the media are full of bias or contaminated by untruths” (8). This allows him to identify three sets of normative standards for the evaluation of the deliberative quality of mass communication. They relate to the diversity and representativeness of the views expressed in the mass media; the quality and expertise of the discourses produced by media elites; and the competitiveness of public debate, which should not be limited by some organizations’ excessive influences or propaganda techniques. 
When applied to the autumn 1990 debate in the New York Times concerning whether or not the United State should go to war with Iraq, this set of standards reveals the defectiveness of the alleged deliberation constructed by the journal. The range of viewpoints represented on the Times' op-ed page was in fact narrow and made the view of the Times' own editorial the center of gravity of the discussion. As a consequence, views favorable to the war were over-represented, social organizations and experts hostile to any military action were ignored, available information about the likely consequences of a military conflict were absent. In brief, this alleged deliberation "did not meet standards of content diversity, presentation of all major points of view, democratic representativeness, or the communication of relevant facts and expertise" (Page 1996, 34). This analysis offers a convincing illustration of the fruitfulness of an approach that does not simply assume that the mass-media dominated public sphere is structurally irrational, but attempts to clarify the conditions for rationality and turn them into standards for the critical analysis of actual media practices. It also showcases the shortcomings of the marketplace of ideas model.

According to Page, the lesson of this case study is that "under certain conditions, certain media outlets may not serve as neutral, passive transmitters of societal ideas and interpretations, but may take an active part as articulators of policy views” (37). When his analysis reveals that the construction of the debate by the Times is biased, he does not denounce the particular bias so much as the construction itself. In fact, because he assumes that mass media could possibly act exclusively as "neutral, passive transmitters", he equates a biased deliberation with a constructed deliberation. Under certain discussions, he argues, "editors at the Times and elsewhere may consciously or unconsciously construct a public debate” (20). To support a genuine deliberative forum, it is assumed that mass media should transmit without determining in any way the 
content which is transmitted. While the unavoidable selection of opinions that mass communication implies makes it clearly impossible to imagine a spontaneous, unconstructed debate via the mass media, this fact is simply obscured by the reference to the marketplace of ideas.

The problem is not only that Page sets low standards for the marketplace of ideas - despite his criticisms of the Times, he ends up concluding that in the current U.S. media system "the marketplace of ideas actually works reasonably well, most of the time” (124). To simply point out the imperfection of the marketplace of ideas - and merely suggest that its failures should be fixed by corrective policies (Coase 1974; Gary 1990) - would be to miss the broader problem. There is simply no reason to believe that "true and useful ideas, once they are enunciated somewhere, have a way of spreading, willy-nilly, everywhere” (Page 1996, 124). Not only does this assumption ignore the many epistemic biases to which free discussion is vulnerable (Sunstein 2006), but it is also blind to the fact that, in order to circulate from one area of the media system to another, an opinion has to go through a series of selection filters, not only neutral transmitters. This blindness makes it impossible to develop a clear view of the conditions for citizens’ participation in the general public sphere.

\section{Who contests? Media elites and citizens' uprisings}

Another of Page's case studies focuses on the channels through which mass communication can generate popular contestation of public policies. When it was revealed, on January 14, 1993, that Zoe Baird, President Clinton's nominee for U.S. Attorney General, had employed two Peruvians living illegally in the US as her chauffeur and nanny, the media elite and the public reacted in strikingly different manners. While the study of opinion polls, letters to newspapers editors and calls to 
members of Congress reveal a reaction of deep public outrage, an analysis of the coverage of the story in the main national newspapers and TV networks indicates that media elites minimized the matter. Surprisingly, however, the public eventually forced the media elites to change discourse (Page 1996, 88). Radio talk-show call-ins had started before the confirmation had begun and before any substantial criticisms of Baird had been expressed in the mainstream media. By January 19, when the confirmation hearings began, public outrage had been vehemently expressed, compelling both members of Congress and mainstream media to adopt a much more critical stance in the coverage of the event, eventually forcing Baird to withdraw her name from consideration for the position on January 22. In Page’s view, “a relatively autonomous popular uprising - based on the bare facts of the case as reported on television, and reinforced by hearing fellow citizens’ anger on talk radio - overcame the complacency of Washington officials and media elites, changed public discourse, and overturned Baird's sure thing confirmation” (89-90).

In this case, the three conditions for contestability might seem to have been satisfied: a) publicity regarding official reasons and relevant facts enabled a public contestation of a political decision based on publicly expressed reasons (such as the integrity of the nominee); b) citizens' claims found media channels to make themselves heard despite the lack of reaction from the media elites; c) Congress was eventually responsive to these claims by submitting Baird to an unexpected, hostile treatment. While he acknowledges that the "Nannygate" was not "an entirely happy story of democratic triumph” (99), as Baird and the illegal immigrants suffered a violent public humiliation partly fuelled by sexism and racism, Page concludes that ordinary citizens were able to impose "not patently unreasonable legal and ethical standards" (100) to a major government appointment despite the failures of the mainstream mass media to 
organize an appropriated deliberation. To this extent, it was "a demonstration that, under certain circumstances, unrepresentative surrogate deliberators can be overcome by direct, populistic deliberation” (100).

This understanding of mass media-supported contestability is, however, problematic. The opposition, in the mass media context, between delegated deliberation, which should be inclusive but sometimes fails to be, and populistic deliberation, which can arise from time to time in order to compensate for the shortcomings of media elites, ultimately rests on two mistaken premises.

First of all, it identifies the particular citizens' voices that manage to make themselves heard through the selection filter of the mass media with the voice of a homogeneous public, and thus ignores the issue of their representativeness, as well as the ways through which they manage to make their opinion prevalent in the general public sphere. What was, in Page's eyes, a popular uprising has been described by other commentators as a partisan action fomented by far-right activists associated with the Republican Party. In James Fishkin’s view, for instance, it was a campaign orchestrated by conservative talk radio shows. "An affecting sound bite led to thousands of listeners feeling sound-bitten. They responded with enraged calls and faxes to members of Congress.” (Fishkin 1997, 973) Focusing on a superficial issue, the public contestation entirely sidetracked, according to Fishkin, the merits and implications of the nomination choice: it was neither rational nor deliberative. Whatever might have been the case in this specific instance, it is clear that Page does not offer any criteria to distinguish between inclusive, reasoned contestation and manufactured, partisan flak, no more than he offers criteria to distinguish between genuine deliberation and non-deliberative communication. Once again, the crude dichotomy between the spontaneous and the constructed is ineffective, because both citizens' engagement in public contestation and 
the deliberative shaping of mass communication require some form of organization and construction. To think otherwise is to rely again on some sort of 'magic'.

Secondly, the delegated/populistic opposition superimposes the distinction between delegation and direct participation on the distinction between professionals (the media elite) and lay citizens (the public). However, to believe that media elites ordinarily act as "representatives" or "delegates” of the public is largely unfounded. While lay citizens might sometimes recognize some of their ideas or interests defended in mass communication, they usually do not feel that media speakers are, in any political sense, acting as their representatives. Moreover, there is no reason to consider that media representation can only be provided by media professionals. Some division of labor is certainly required if mass communication is to enjoy a deliberative dimension. Nevertheless, we should not assume that the need for social groups to accumulate media resources and skills automatically translate into the emergence of a specific cast endowed with representative authority. The frontiers separating the respective functions of journalists, media experts and spokespersons for social groups should not be blurred if one wants to avoid relegating citizens' participation to the exceptional - and truly "heroic", as Pettit would say, - uprisings. While only a few voices can gain maximal visibility on the mass media stage, there is no reason to renounce the inclusion of lay citizens and social movements' spokespersons alongside the media elites, in order to participate in the evaluation of public policies.

External standards ensuring adequate media pluralism are simply not enough to create the conditions for public contestation in the general public sphere. The lack of cultural, economic, racial or gender representativeness frequently observed in mass communication, and the frequent irrationality of public reactions it provokes, are clear 
enough indications of the fact that economic competition between a diversity of media outlets does not make for sufficient inclusiveness or rationality.

\section{Towards mass deliberation: resources for mass media regulation}

Mass deliberation requires much more than a marketplace. It requires internal regulation guided by deliberative standards, which relate, among other things, to systematic reason-giving, representativeness of published opinions, and fair access to media speech. The prospect of deliberative media regulation - going beyond the promotion of media pluralism - in the name of contestatory democracy, is likely to raise fierce objections.

First of all, one could argue that the rise of the digital media and the increasingly easy access to media speech for lay citizens has abolished the selection process, and with it the need for regulation. In the twenty years since the radio talk shows triumphed in "Nannygate", media systems have been drastically restructured. Indeed, political communication no longer happens in a media environment exclusively dominated by professional journalistic gatekeepers, as in the old media regime (White, 1950). But that is not to say that the selection process itself has disappeared. Rather, it has become more fragmented, diffuse and competitive: a multitude of gatekeepers with divergent motivations and opinions have replaced the limited, unified selection system of the previous era (Williams and Delli Carpini 2011). While a growing diversity of habits, goals and ideologies preside over the transmitting and framing of media discourses, only a small minority of these discourses reaches the mass media and gain maximum public visibility. Media power remains, first and foremost, a selection power, related to the "sheer force of mass distribution of information" (Schudson 2003, 28), even when it 
is exerted in a fragmented, uncoordinated way by a multiplicity of media agents. The fragmentation and lack of coordination only make regulation more urgent, if more difficult.

Furthermore, any project of regulation by the state might appear to threaten media independence by creating opportunities to impose excessive restrictions on the freedom of the press. The state might be as corrupting an influence as the market. But regulation does not need to come exclusively from the state. In a pluralist media system - whether it corresponds to "polarized pluralist”, “democratic corporatist” or "liberal” model (Hallin and Mancini 2004) -, a pluralist regulation can be conceived. Such pluralist regulation must combine self-regulation, informal social regulation and legal regulation. In particular, a plurality of media agents can act together, in the absence of centralized coordination but in partial agreement on the normative standards associated with contestatory democracy, to contribute to making the general public sphere an appropriate forum for public contestation. It does not require all media agents to be exclusively motivated by the ideal of contestatory democracy. It does require, however, that the normative resources already existing in journalism ethics, media criticism and media law be exploited and developed. This is all the more plausible given that journalistic, social and legal conceptions of media regulation have, for a long time, if often ineffectively, been driven by the idea that the first social responsibility of the mass media is to create a forum for democratic deliberation (Siebert, Peterson and Schramm 1956).

The self-regulation of the media system starts with journalistic ethics. While lay citizens play a growing role in the mass media selection process, the influence of professional journalists remains paramount, especially when it comes to filtering discourses that circulate in areas of medium visibility so as to make them reach 
maximum visibility. Ethical rules embedded in journalistic habits, codes of deontology, international or national professional guidelines, and alternative standards put forward by social movements such as public journalism (Dzur, 2002), although not binding and oftentimes ignored, play an actual role in media practice and constitute a powerful, if insufficient, source of regulation. The practice of demanding reasons from political institutions and holding them accordingly accountable - something that is required to unearth a basis for contestation - is at the core of journalism, conceived not only in its role of providing information, but also in its role of enhancing deliberation (Ettema, 2007).

Critical evaluation of media practices is not only produced by journalists themselves, but constantly fed by (lay or expert) media criticism. While sometimes reluctant to endorse a positive theory of democratic deliberation, media critics tend to focus on the lack of inclusiveness, representativeness and rationality in the mass media's construction of mass communication. For more than a century, radical media criticism has denounced the stifling of minority voices and the biased construction of discursive confrontations (Mc Chesney and Scott 2004). When Pierre Bourdieu condemns the "de facto monopoly" of a media elite "on the large-scale informational instruments of production and diffusion of information (Bourdieu, 1996, 46), he points to the bias in the selection process. The problem, in his view, is the control media elites exert on the access of ordinary citizens to the public sphere: discourses "have to face this trial of journalistic selection in order to catch the public eye. The effect is censorship, which journalists practice without even being aware of it.” (47) While such criticism remains incomplete without a proper conception of what an appropriate massmedia structured public sphere could and should look like, it contributes in submitting media practices to normative standards. 
Self-regulation and informal social regulation can neither thrive nor contribute to endowing mass communication with a deliberative dimension without an appropriate legal framework. Legal regulation, when it is not stringently limited by the reference to the marketplace of ideas, is already aiming at promoting an (admittedly vague) idea of public debate, thus justifying, for instance, public subsidies for media outlets satisfying specific standards. Existing restrictions on media ownership, or proposals to institutionalize principles such as net neutrality, offer a clear idea of the already existing trends towards ambitious regulation and of how quickly they can be made meaningless by empty reforms or anti-regulation policies (Baker 2007, Lunt and Livingstone 2012). Since speech in the areas of maximum visibility is a limited good, to bestow upon each citizen an equal formal right to freedom of expression is not enough to ensure fair access to speech in the mass media: legal rules are needed to make sure that asymmetries in media resources and media power do not transform an equal formal right into deeply unequal opportunities to participate in, and thereby influence, the public evaluation of public policies.

The contestability of public policies is an essential feature of democratic regimes, which deliberative theory should promote. It requires deliberative, inclusive and responsive institutions. But it can only be made democratic if the evaluation of citizens' claims is not entirely delegated to experts. A general public forum, supported by the mass media, should make it possible for all to form a deliberate judgment at least on some of the most important issues. This can only be made possible if this forum is not reduced to a "marketplace of ideas": effective media regulation, going beyond the promotion of media pluralism, need to contribute in endowing it with a deliberative dimension. Current media practices might make the idea of a mass media-structured 
forum implausible, if not downright naïve. Political theory should not confuse, however, structural necessities and contingent pathologies. Conceptual resources are not lacking to elaborate a deliberative theory of the mass media.

Acknowledgments

I thank Selen A. Ercan, Florence Hulak, Matthew Udkovich and an anonymous reviewer for their precious comments on a first draft of this paper.

References:

Baker, C. E. 2007. Media Ownership and Democracy. Why Ownership Matters, Cambridge: Cambridge University Press.

Barabas, J. 2004. “How Deliberation Affects Policy Opinions.” American Political Science Review, 98 (4): 687-701.

Blocher, J. “Institutions in the Marketplace of Ideas.” Duke Law Journal 57 (4): 821889.

Bourdieu, P. (1996). On Television, transl. P. Parkhurst Ferguson. New York: The New Press.

Calhoun, C. (ed.) 1992. Habermas and the Public Sphere. Cambridge, Mass.: The MIT Press.

Chambers, S. 2012. “Deliberation and Mass Democracy”, in Deliberative Systems:

Deliberative Democracy at the Large Scale, edited by John Parkinson and Jane Mansbridge, 52-71. Cambridge: Cambridge University Press.

Chambers, S., Costain (ed.), A., 2000. Deliberation, Democracy and the Media, Oxford: Rowman and Littlefield. 
Church, S. H. 2010. "YouTube Politics: YouChoose and Leadership Rhetoric During the 2008 Election.” Journal of Information Technology \& Politics 7 (2-3): 124-142.

Coleman S., Blumler J. G., 2009. The Internet and Democratic Citizenship. Theory, Practice, Policy. Cambridge: Cambridge University Press.

Coleman, S. 2013. “Debate on Television: The Spectacle of Deliberation.” Television and New Media, 14 (1): 20-30.

Coase, R. H. 1974. “The Economics of the First Amendment: The Market for Goods and the Market for Ideas.” American Economic Review, 64: 384-391.

Dahl, R. 1956. A Preface to Democratic Theory. Chicago: Chicago University Press. Dahlgren, P. 2009. Media and Political Engagement: Citizens, Communication, and Democracy. Cambridge: Cambridge University Press.

Dryzek, J. 2006. Deliberative Global Politics. Discourse and Democracy in a Divided World, Cambridge: Polity.

Dryzek, J. 2010. Foundations and Frontiers of Deliberative Governance. Oxford: Oxford University Press.

Dzur, A. W. 2002. "Public Journalism and Deliberative Democracy.” Polity 34 (3): 313336.

Ettema, J. S. 2007. “Journalism as Reason-Giving: Deliberative Democracy, Institutional Accountability, and the News Media’s Mission”, Political Communication 24: $143-160$.

Fishkin, J. 1997. “Review on Benjamin Page, Who Deliberates?” American Political Science Review, 91 (4): 972-973.

Gary, P. M. 1990. The American Vision of a Free Press. An Historical and Constitutional Revisionist View of the Press as a Marketplace of Ideas. New York: Garland. 
Gripsrud, J., Moe, H., Molander, A., Murdock, G. (ed.) 2011. The Public Sphere. Vol. IIV, London: Sage.

Habermas, J. (1962) 1989. The Structural transformation of the Public Sphere. An Inquiry into a Category of Bourgeois Society. Cambridge, Mass.: MIT Press. Habermas, J. (1990) 1992. “Further Reflections on the Public Sphere”, in C. Calhoun (ed.). Habermas and the Public Sphere. Cambridge, Mass.: The MIT Press, 421-261. Habermas, J. 1992 (1997) Between Facts and Norms: Contributions to a Discours Theory of Law and Democracy, trans. W. Rehg, Cambridge, Polity Press.

Habermas, J. 2006. "Political Communication in Media Society: Does Democracy Still Enjoy an Epistemic Dimension? The Impact of Normative Theory on Empirical Research.” Communication Theory 16: 411-426.

Hallin D. C., Mancini, P. 2004. Comparing Media Systems. Cambridge: Cambridge University Press.

Harris, C., Rowbotham, J., Stevenson, K. 2009. “Truth, law and hate in the virtual marketplace of ideas: perspectives on the regulation of Internet content.” Information \& Communications Technology Law 18 (2): 155-184.

Keane, J. 2013. Democracy and Media Decadence. Cambridge: Cambridge University Press.

Klocke, B., McDevitt, M. 2013. “Foreclosing Deliberation.” Journalism Studies 14 (6): 891-906.

Lunt, P., Livingstone S., Media Regulation: governance and the Interests of Citizens and Consumers, London: Sage.

Pettit, P. 1997. Republicanism. A Theory of Freedom and Government. Oxford: Oxford University Press. 
Pettit, P. 2012. On the People's Terms. A Republican Theory and Model of Democracy. Cambridge: Cambridge University Press.

Page, R. 1996. Who Deliberates? Mass Media in Modern Democracy, Chicago:

Chicago University Press.

Parkinson, J. 2006. "Rickety Bridges: Using the Media in Deliberative Democracy.” British Journal of Political Science, 36: 175-183.

Parkinson, J., Mansbridge, J. 2012. Deliberative Systems: Deliberative Democracy at the Large Scale. Cambridge: Cambridge University Press.

Rousiley C. M. M. 2012. Deliberation, The Media and Political Talk. New York: Hampton Press.

Rousseau J. J. (1762) 1997. Rousseau:'The Social Contract' and Other Later Political Writings, trans. V. Gourevitch. Cambridge: Cambridge University Press.

Schmuhl, R., Picard R. G., “The Marketplace of Ideas”, in G. Overholser and K. Jamieson (ed.), The Press. Oxford: Oxford University Press, 141-155.

Schudson, M. 2003. The Sociology of News. New York: W. W. Norton \& Company.

Siebert, F. S., Peterson, T., Schramm, W. (1956). Four Theories of the Press. Urbana, IL: University of Illinois Press.

Stigler, G. 1971. “The Theory of Economic Regulation.” Bell Journal of Economics and Management Science 2: 3-21.

Truman, D. 1951. The Governmental Process. New York: Knopf.

White, D. M. 1950. “The Gate Keeper.” Journalism Quarterly, 27: 383-390.

Williams, B. A., Delli Carpini, M. X. 2011. After Broadcast News. Media Regimes, Democracy and the New Information Environment, Cambridge: Cambridge University Press. 